\title{
Lusioersily
}

\section{Experimental characterisation of a flat panel integrated collector-storage solar water heater featuring a photovoltaic absorber and a planar liquid-vapour thermal diode}

Pugsley, A., Mondol, J., Smyth, M., Zacharopoulos, A., \& Di Mattia, L. (2016). Experimental characterisation of a flat panel integrated collector-storage solar water heater featuring a photovoltaic absorber and a planar liquidvapour thermal diode. In V. Martinez, \& J. Gonzalez (Eds.), Proceedings of 11th ISES EuroSun Conference: Palma (Mallorca), Spain from 11 to 14 October 2016 International Solar Energy Society. https://doi.org/10.18086/eurosun.2016.08.14

Link to publication record in Ulster University Research Portal

\section{Published in:}

Proceedings of 11 th ISES EuroSun Conference

Publication Status:

Published (in print/issue): 14/08/2016

DOI:

10.18086/eurosun.2016.08.14

\section{Document Version}

Publisher's PDF, also known as Version of record

\section{General rights}

Copyright for the publications made accessible via Ulster University's Research Portal is retained by the author(s) and / or other copyright owners and it is a condition of accessing these publications that users recognise and abide by the legal requirements associated with these rights.

\section{Take down policy}

The Research Portal is Ulster University's institutional repository that provides access to Ulster's research outputs. Every effort has been made to ensure that content in the Research Portal does not infringe any person's rights, or applicable UK laws. If you discover content in the Research Portal that you believe breaches copyright or violates any law, please contact pure-support@ulster.ac.uk. 


\title{
Experimental characterisation of a flat panel integrated collector-storage solar water heater featuring a photovoltaic absorber and a planar liquid-vapour thermal diode
}

\author{
Adrian Pugsley ${ }^{1}$, Mervyn Smyth ${ }^{1}$, Jayanta Deb Mondol ${ }^{1}$, \\ Aggelos Zacharopoulos ${ }^{1}$, Luigi Di Mattia ${ }^{2}$ \\ 1 Ulster University, Faculty of Art, Design and the Built Environment, \\ Centre for Sustainable Technologies, Belfast (UK) \\ 2 University of Naples "Federico II", Dept. Energy Applied Thermal Fluid Dynamics \& \\ Environmental Influences, Naples (Italy)
}

\begin{abstract}
A flat panel Integrated Collector-Storage Solar Water Heater (ICSSWH) incorporating a photovoltaic-thermal (PVT) absorber and a Planar Liquid-Vapour Thermal Diode (PLVTD) was fabricated. Tests indicate zero temperature rise instantaneous thermal and electrical efficiencies of $60 \%$ and $9 \%$ respectively, dropping to $40 \%$ and $6 \%$ under nominal intended operating conditions $\left(600 \mathrm{Wm}^{-2}\right.$ irradiance, $50^{\circ} \mathrm{C}$ storage tank, $20^{\circ} \mathrm{C}$ ambient temperature). Measured overall heat loss coefficient was $0.85 \mathrm{Wm}^{-2} \mathrm{~K}^{-1}$ and thermal diode conductances were typically $45 \mathrm{Wm}^{-2} \mathrm{~K}^{-1}$ during solar collection periods and $1.7 \mathrm{Wm}^{-2} \mathrm{~K}^{-1}$ during heat retention periods. The work demonstrates that ICSSWH, PVT and PLVTD concepts can be successfully combined to create a scalable flat panel solar collector suitable for integration within a multifunction building facade.
\end{abstract}

Keywords: Integrated-Collector-Storage Solar Water Heater (ICSSWH), Photovoltaic-Thermal (PV/T), Building Integrated Solar Thermal (BIST), Building Integrated Photovoltaic (BIPV), Thermal Diode

\section{Introduction}

This paper presents key findings of experimental investigations undertaken to characterise behaviour of a flat panel Integrated Collector-Storage Solar Water Heater (ICSSWH) incorporating a photovoltaic-thermal (PVT) absorber and a Planar Liquid-Vapour Thermal Diode (PLVTD). This new hybrid solar collector type is intended for integration within multifunction building façades to provide low temperature hot water and electrical power to buildings. The paper briefly introduces the concept and cites influential prior work. The theoretical basis for the concept is outlined and modelling results are presented which demonstrate how collection, retention and diurnal thermal efficiencies are influenced by diode thermal conductances. Methodology and results of the experimental investigation are presented. Measurement results are compared to those typically achieved by comparable collector types and recommendations are made for future work.

\subsection{Thermal and photovoltaic solar collectors}

The Renewable Energy Directive (EU, 2009) sets a target of $20 \%$ of EU gross final energy consumption to be supplied from renewables by 2020. Increasing solar energy utilization plays a key role in meeting the target. Solar Thermal (ST) systems are expected to make a significant contribution to renewable heat targets in addition to renewable electricity supplied by already popular PhotoVoltaic (PV) systems. Traditionally, building mounted ST competes with PV for suitable roof or façade space. Combining technologies gives rise to PhotoVoltaic-Thermal (PVT) solutions which deliver low to medium temperature solar heat at efficiencies marginally lower than conventional ST collectors and generate electricity similar to standard PV modules. 
Careful design is necessary as most building thermal demands require heat to be delivered at temperatures significantly above ambient which reduces both thermal and electrical efficiencies. Domestic hot water, space heating and cooling systems which combine, ST, PV or PVT collectors with heat pumps appear to be a promising development area and a popular subject for current applied research (Good et al., 2015; Aguilar et al., 2016; Calise et al., 2016; Poppi et al., 2016; Qu et al. 2016).

Zondag (2008) gives a comprehensive review of PVT collector development, covering both air and water heating variants. More recent reviews are given by Michael et al. 2015 and Besheer et al. 2016. Santbergen et al. (2010) and Dupeyrat et al. (2011) specifically examine module design, construction, and heat transfer aspects of PVT-water collectors for domestic hot water production. Most PVT-water collectors take the form of photovoltaic cell laminates glued or bonded to sheet-and-tube, flow channel, or roll-bond type solar thermal absorbers. Packing Factor (PF) is the ratio of PV cell area to total absorber area. Thermal efficiency is maximized by ensuring absorber substrates are matt black or selectively coated to maximize solar thermal input. Bonding layers between PV cells and absorber substrates should be thin and thermally conductive. Convective heat transfer within the working fluid should be promoted. Zondag (2008) cites PVT-water collector examples featuring overall cell-to-fluid conductances in the range 40 to $250 \mathrm{Wm}^{-2} \mathrm{~K}^{-1}$. Low conductances increase PV cell temperatures which reduce both electrical and thermal efficiencies. Thermal efficiencies of PVT collectors are typically lower than those of dedicated ST collectors due to lower absorption coefficients of encapsulated PV cells $(0.7 \leqq \alpha \leqq 0.9$ as opposed to $\alpha=0.95$ for matt black surfaces $)$ and also because some of the available energy $\left(15<\eta_{\mathrm{E}(0, \mathrm{mpp})}<20 \%\right.$ typically for crystalline silicon cells $)$ is extracted as electricity. Silicon cells produce a nominal voltage of $0.55 \mathrm{~V}$ per cell but this reduces significantly with increasing temperature $\left(\sim 0.45 \% /{ }^{\circ} \mathrm{C}\right)$ and falls markedly under low irradiance conditions (below about $200 \mathrm{Wm}^{-2}$ ). Photovoltaic current is directly proportional to irradiance and only slightly temperature dependent. Temperature nonuniformities across PVT absorber surfaces can significantly reduce electrical efficiency if cells are connected in parallel but generally have minimal effect on series connected cells.

Smyth et al. (2006) present a thorough review of Integrated Collector-Storage Solar Water Heaters (ICSSWH). These collectors can be significantly more cost effective than conventional ST systems because they have fewer components and require less floor space for water storage tanks. However, inherent exposure of the thermal storage to the outdoor environment (via the absorber surface) means that ICSSWH collectors suffer from heat loss at night and during periods of low insolation, particularly if installed in cold and windy climates. Most ICSSWH designs utilize one or more transparent covers to reduce heat loss. Various researchers have examined the use of novel techniques to improve heat storage effectiveness in ICSSWH collectors, including use of reflectors, concentrators, inlet diffusers, baffles, sleeves, phase change materials and thermal diodes. A recent review by Singh et al. (2016) attempts to categorise ICSSWH designs according to whether they are non-concentrating (eg flat plate or tank box systems), concentrating (eg compound parabolic) or employing phase change materials. Performance comparisons between different ICSSWH collectors are commonly made by considering collection efficiencies (typically $15<\eta_{\text {col }}<50 \%$ ), overall heat loss coefficients (typically $2<\mathrm{U}_{\text {sys }}<7 \mathrm{Wm}^{-2} \mathrm{~K}^{-1}$ ), and maximum daily stored water temperatures (typically $30<\mathrm{T}_{\max }<60^{\circ} \mathrm{C}$ ).

Façade mounted Building Integrated (BI) solar collectors (BIST, BIPV and BIPVT) offer viable alternatives to bolt-on roof mounted collectors if structural, functional, aesthetic and cost considerations are addressed holistically to achieve high quality architecturally integrated solutions. Combining façade integrated BIPVT with improved ICSSWH technology potentially offers attractive and cost effect solutions for new buildings and refurbishments, particularly in multi-tenanted dwellings, hotels, and hospitals which have significant demands for low temperature heat and typically have limited roof-space available for solar collectors.

\subsection{Thermal diodes and development of the PVT-PLVTD-ICS concept}

A thermal diode is a unidirectional heat flow device analogous to an electrical semiconductor diode which offers low resistance to heat flow in one direction and higher resistance in reverse. Most studies involving thermal diodes focus on liquid convective devices (Kolodziej et al., 1997; Mohamad, 1997; Chen et al., 1998; Smyth et al., 1999; Faiman et al., 2001; Sopian et al., 2004; Fang \& Xia, 2010; Rhee et al., 2010) but few consider phase change diode concepts. De Beijer (1998) proposed a horizontal cylindrical building integrated roof-ridge ICSSHW employing a liquid-vapour-liquid phase change thermal diode. Studies from Ulster 
University (Quinlan et al., 2008; Quinlan, 2010; Souliotis et al., 2011) fabricated and tested similar devices in both horizontal and vertical orientations. The best of several $\sim 25 \mathrm{~L} / \mathrm{m}^{2}$ prototypes investigated by Quinlan (2010) was DVICS Mark VI which achieved $\eta_{\text {col }}=38 \%, \mathrm{~T}_{\max }=44^{\circ} \mathrm{C}$ and $\mathrm{U}_{\text {sys }}=1.3 \mathrm{Wm}^{-2} \mathrm{~K}^{-1}$ during solar simulator tests. These performances (particularly heat loss coefficients) compare favourably with values reported in Section 1.1. Calculations based on Quinlan's results suggest that the $\mathrm{x} \approx 25 \mathrm{~mm}$ wide thermal diode in DVICS Mark IV offered $\mathrm{U}_{12 \mathrm{f}} \approx 20 \mathrm{Wm}^{-2} \mathrm{~K}^{-1}$ during collection periods and $\mathrm{U}_{12 \mathrm{r}} \approx 2 \mathrm{Wm}^{-2} \mathrm{~K}^{-1}$ during retention periods. Boreyko et al. (2011) and Boreyko \& Chen (2013) investigated planar jumping-drop liquid-vapourliquid thermal diodes primarily aimed at microelectronics cooling applications, but recognised their potential use in solar collectors. High conductances of $\mathrm{U}_{12 \mathrm{f}}=40500 \mathrm{Wm}^{-2} \mathrm{~K}^{-1}$ and $\mathrm{U}_{12 \mathrm{r}} \approx 165 \mathrm{Wm}^{-2} \mathrm{~K}^{-1}$ were reported, seemingly enabled by highly effective evaporator wetting, thorough removal of non-condensable gases, and small diode cavities $(\mathrm{x} \approx 2.5 \mathrm{~mm})$. Thermal diode behavior is eminently suited to ICSSWH applications which inherently require rapid heat transfer from absorber to storage tank during sunny daytime periods (collection/forward mode) and thermal insulation to minimise tank heat losses during cloudy and overnight periods (retention/reverse mode). Unfortunately, the reverse mode conductances achieved by Boreyko et al. are unlikely to be beneficial in reducing tank heat losses. Recent work at Ulster University has progressed the patented vertical cylindrical liquid-vapour-liquid phase change thermal diode ICSSWH concept (Smyth, 2015) and evaluated commercial feasibility (Solaform, nd). Several design variants are currently evolving, aimed at cost reduction, improved evaporator wetting, and flattened forms compatible with PVT and building façade integration (Smyth et al., 2015 \& 2016; Pugsley, 2017). The present paper details results of tests undertaken on the first truly flat panel prototype, the design of which is shown in Figure 1. Unlike previous design variants, the prototype examined in this study features resin-bonded PV cells and the liquid-vapour thermal diode has a much wider cavity $(x=70 \mathrm{~mm})$ than any others encountered in the literature with the aim of reducing overnight heat losses. The diode is planar in form to facilitate building façade integration and features a novel internal support structure similar to that employed in vacuum glazing (Fang et al., 2004).

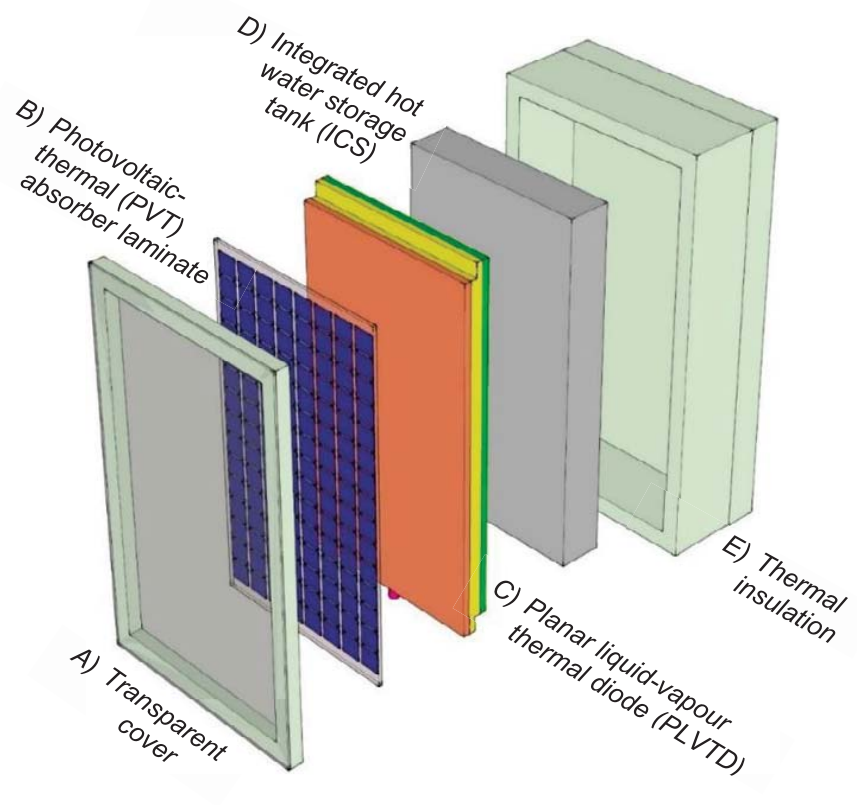

Figure 1 - General arrangement of a PVT-PLVTD-ICS solar collector

\section{Theory}

Heat collection $\left(\eta_{\text {col }}\right)$ and retention $\left(\eta_{\text {ret }}\right)$ efficiencies and system heat loss coefficients $\left(U_{\text {sys }}\right)$ for ICSSWH collectors can be defined (after Smyth et al., 1999 and Faiman et al. 2001) using Equations 1 to 3 based on total heat capacity $\left(\mathrm{C}_{\mathrm{tot}}\right)$, water storage tank temperatures $\left(\mathrm{T}_{3[\mathrm{t}]}\right)$ at dawn $\left(\mathrm{t}=\mathrm{t}_{0}\right)$, dusk $\left(\mathrm{t}=\mathrm{t}_{0}+\mathrm{t}_{\mathrm{col}}\right)$ and the subsequent dawn $\left(\mathrm{t}=\mathrm{t}_{0}+\mathrm{t}_{\text {col }}+\mathrm{t}_{\text {ret }}\right)$, retention period average ambient temperatures $\left(\widetilde{T}_{a}\right)$, collection period average 
incident irradiance $(\tilde{G})$, and collector area (A). The overall diurnal efficiency $\left(\eta_{\mathrm{T}+\mathrm{E}, 24}\right)$ of a PVT-ICSSWH can be expressed in terms of the product of the collection and retention efficiencies plus the electrical efficiency, as per Equation 4, where instantaneous electrical power is determined from the product of current (I) and voltage (V) supplied to an electrical load. Diurnal thermal efficiency is a relative performance measure where $\eta_{\mathrm{T} 24}=1$ indicates perfect solar thermal collection and retention without losses and $\eta_{\mathrm{T} 24}=0$ implies either no heat collection, total overnight heat loss, or both. Values of $0<\eta_{\mathrm{T} 24}<1$ indicate potential for useful net heat gain provided that Equation 5 is satisfied.

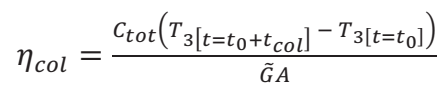

$$
\begin{aligned}
& \eta_{\text {ret }}=\frac{T_{3\left[t=t_{0}+t_{c o l}+t_{r e t}\right]}-\tilde{T}_{a}}{T_{3\left[t=t_{0}+t_{c o l}\right]}-\tilde{T}_{a\left[t=t_{0}+t_{c o l}\right]}} \\
& U_{L}=\frac{C_{t o t}}{A \cdot t_{r e t}} \ln \frac{1}{\eta_{r e t}} \\
& \eta_{T+E, 24}=\eta_{T 24}+\eta_{E 24}=\eta_{c o l} \eta_{r e t}+\frac{\int_{t_{0}}^{t_{0}+t_{c o l}+t_{r e t}} I V}{\tilde{G} A} \\
& \eta_{T 24} \tilde{G} A+C_{t o t}\left(\overline{T_{3\left[t=t_{0}\right]}-T_{a}}\right)\left(\eta_{\text {ret }}-1\right)>0
\end{aligned}
$$

Equations 6,7 \& 8 describe how ICSSWH collector instantaneous thermal efficiencies $\left(\eta_{\mathrm{T}, \text { col }}\right.$ during collection and $\eta_{\mathrm{T}, \text { ret }}$ during retention periods) are determined by the solar power input (GA); transmission-absorption product $(\tau \alpha)$; and the absorber $\left(\mathrm{T}_{1}\right)$, tank $\left(\mathrm{T}_{3}\right)$, and ambient $\left(\mathrm{T}_{\mathrm{a}}\right)$ temperatures. These equations were derived by Pugsley (2017) based on a lumped parameter model which considers the thermal resistances associated with absorber-to-tank heat transfer $\left(\mathrm{R}_{123}=\mathrm{R}_{12}+\mathrm{R}_{23}\right)$, absorber-to-ambient heat loss $\left(\mathrm{R}_{1 \mathrm{a}}\right)$ and insulated tank envelope heat losses $\left(R_{3 i a}\right)$. Conductance $U_{12}=1 /\left(A \cdot R_{12}\right)$ describes diode behaviour and conductance $U_{23}=1 /\left(A \cdot R_{23}\right)$ represents water storage tank natural convection. Conductance $U_{1 a}=1 /\left(A \cdot R_{1 a}\right)$ represents combined radiative heat transfer and air mass natural convection effects occurring between the absorber and its transparent insulating cover, and also between the transparent cover and the external environment.

$$
\begin{aligned}
& \eta_{T(\mathrm{col})}=\frac{\left(T_{1}-T_{3}\right) / R_{123}-\left(T_{3}-T_{a}\right) / R_{3 i a}}{G A} \\
& \eta_{T(r e t)}=\frac{C_{t o t}\left(T_{3}-T_{a}\right)+t_{r e t}\left[\left(T_{3}-T_{a}\right) / R_{123}-\left(T_{3}-T_{a}\right) / R_{3 i a}\right]}{C_{t o t}\left(T_{3}-T_{a}\right)} \\
& T_{1}=\frac{R_{123} T_{a}+R_{1 a} T_{3}}{R_{1 a}+R_{123}}=\frac{R_{123} R_{1 a} \tau \alpha G A+T_{a} R_{123}+T_{3} R_{1 a}}{R_{123}+R_{1 a}}
\end{aligned}
$$

The theoretical relationship between diurnal thermal efficiency and water storage tank temperature is shown on Figure 2 for various diode performance scenarios. The analysis was undertaken by calculating the product of Equations $6 \& 7$ for nominal $\mathrm{G}=500 \mathrm{Wm}^{-2}, \mathrm{t}_{\mathrm{ret}}=64800 \mathrm{~s}, \mathrm{~A}=1 \mathrm{~m}^{2}, \tau \alpha=0.81$, and $\mathrm{U}_{3 \mathrm{ia}}=0.3 \mathrm{Wm}^{-2} \mathrm{~K}^{-1}$ using temperature dependent values of $3<\mathrm{U}_{1 \mathrm{a}}<5 \mathrm{Wm}^{-2} \mathrm{~K}^{-1}$ and $100<\mathrm{U}_{23}<1000 \mathrm{Wm}^{-2} \mathrm{~K}^{-1}$ which were evaluated using well known Rayleigh-Nusselt convection and Stefan-Boltzmann radiation heat transfer equations (Cengel, 2006). Equilibrium absorber temperatures $\left(T_{1}\right)$ during collection periods were found by iteration to satisfy Equation 8. Temperature dependent collection/forward mode $\left(\mathrm{U}_{12 \mathrm{f}}\right)$ and retention/reverse mode $\left(\mathrm{U}_{12 \mathrm{r}}\right)$ diode conductances (see legend of Figure 1) were determined from experimental and theoretical work on PLVTDs by Pugsley (2017). Figure 2 indicates that the benchmark single glazed collector with no thermal diode (A) achieves $\eta_{\mathrm{T} 24}=37 \%$ when the tank temperature is low (close to a zero daytime heat loss operating condition $\left[\mathrm{T}_{3}-\mathrm{T}_{\mathrm{a}}\right] / \mathrm{G}=0$ ) and a nominal mild-climate night-time heat loss condition $\left[\mathrm{T}_{3}-\mathrm{T}_{\mathrm{a}}\right]=15^{\circ} \mathrm{C}$ occurs. Performance decreases with increasing tank temperature such that $\eta_{\mathrm{T} 24}=9 \%$ occurs for a hypothetical daytime condition of $\left[\mathrm{T}_{3}-\mathrm{T}_{\mathrm{a}}\right] / \mathrm{G}=0.1 \mathrm{~m}^{2} \mathrm{KW}^{-1}$ followed by a cold night-time period where $\left[\mathrm{T}_{3}-\mathrm{T}_{\mathrm{a}}\right]=70^{\circ} \mathrm{C}$. Addition of a basic thermal diode (B) yields a 1.5 times improvement in low temperature performance $\left(\eta_{\mathrm{T} 24}=56 \%\right)$ and doubles the high 
temperature performance $\left(\eta_{\mathrm{T} 24}=18 \%\right)$. Use of a high performance diode (E) yield a 1.7 times improvement in low temperature performance $\left(\eta_{\mathrm{T} 24}=61 \%\right)$ and a 2.3 times improvement in high temperature performance $\left(\eta_{\mathrm{T} 24}=21 \%\right)$. These improvements in diurnal thermal efficiency are primarily due to improved (reduced) reverse mode conductance (D) which improves heat retention efficiency, rather than increased forward mode conductance (C) which has only a limited effect on collection efficiency.

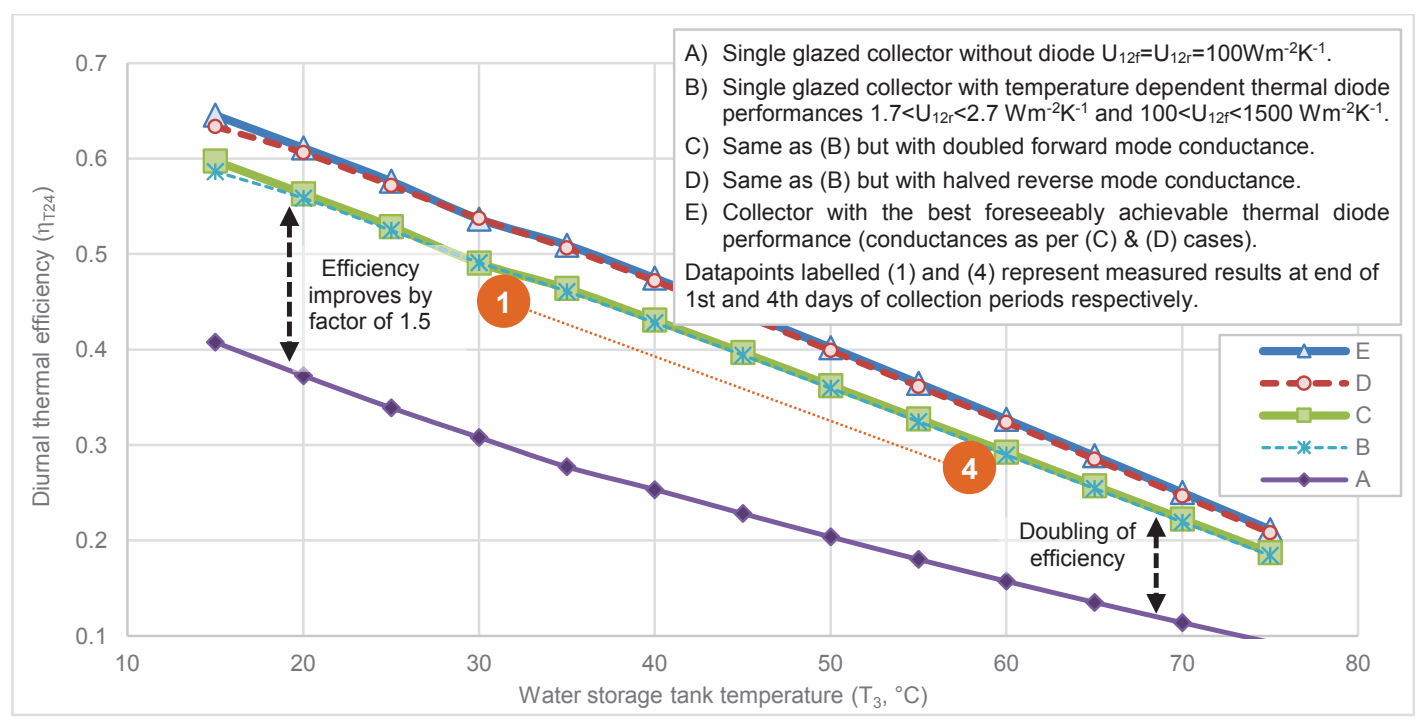

Figure 2 - Effect of diode thermal conductance upon diurnal thermal efficiency of an ICS collector

\section{Experimental methodology}

A prototype taking the form shown in Figure 1 was fabricated. The thermal diode and water storage tank (see Figures 3, 5a and Table 1) were formed of folded and welded stainless steel sheet supported internally by an array of stainless steel tubular struts. A welded vacuum flange was added to enable working fluid addition and chamber evacuation through the top of the unit. A stainless steel manifold plate was welded to the bottom to enable connection of the evaporator wetting mechanism (Intellectual Property considerations prevent us from describing this in detail). The completed steelwork was tested for storage tank water leaks and diode vacuum leaks (Figure 5c). The PVT absorber was then formed on the diode's absorber-evaporator plate (see Figure 4, $5 \mathrm{~b}$ and Table 1) using matt black paint, double-sided adhesive foam tape, quartered mono-crystalline silicon cells, transparent silicone resin, and transparent Perspex cover plates. The series-parallel interconnected PV cells were connected to a $5.2 \Omega$ resistive load bank. Prior to resin casting, T-Type Thermocouples (TTC) producing measurement results with standard uncertainty $\pm 0.3^{\circ} \mathrm{C}$ in the range 0 to $100^{\circ} \mathrm{C}$ were attached to the rear of four PV cells $\left(\mathrm{T}_{0}\right)$ and to the absorber-evaporator plate surface at twelve locations $\left(\mathrm{T}_{1}\right)$. Fourteen TTCs were bonded to the condenser-tank plate surface $\left(\mathrm{T}_{2}\right)$ within the tank, along with five TTCs mounted along a thin vertical wire suspended in the water $\left(\mathrm{T}_{3}\right)$. Thirteen TTCs were bonded to outer surfaces of diode sidewalls $\left(\mathrm{T}_{4}\right)$ and sump $\left(\mathrm{T}_{\mathrm{S}}\right)$ and three were placed in shaded and sheltered locations to measure ambient temperatures $\left(\mathrm{T}_{\mathrm{a}}\right)$. All TTCs were connected to a Delta-T Devices DL2e datalogger sampling continuously and recording average temperatures at 5 minute intervals. Thermally insulating polystyrene foam was applied to the rear and sides of the prototype along with a transparent Perspex sheet to cover the absorber.

The diode was filled with $1 \mathrm{~kg}$ of working fluid and evacuated to $\sim 2.5 \mathrm{kPa}$ (close to saturated vapour pressure of water at $20^{\circ} \mathrm{C}$ ) using an Edwards XDS5 scroll vacuum pump and a Druck DPI-104 vacuum pressure gauge. The completed prototype was initially tested for heat retention performance by filling the tank with hot water at $\mathrm{T}_{3}=70^{\circ} \mathrm{C}$ and measuring the rate of temperature reduction overnight. The test was repeated with additional polystyrene insulation over the absorber which enabled tank back and sides heat loss to be quantified as $\mathrm{U}_{3 \mathrm{ia}}=1.1 \mathrm{Wm}^{-2} \mathrm{~K}^{-1}$ at $70^{\circ} \mathrm{C}$ and $\mathrm{U}_{3 \mathrm{ia}}=0.6 \mathrm{Wm}^{-2} \mathrm{~K}^{-1}$ at $40^{\circ} \mathrm{C}$ (estimated standard uncertainty $\pm 0.2 \mathrm{Wm}^{-2} \mathrm{~K}^{-1}$ ). The tank was then drained and the prototype moved to Ulster University's solar simulator facility (Zacharopoulos et al., 2009). The main tests under the simulator followed similar methodologies and procedures to those used 
by Quinlan (2010) and Smyth et al. (2015) although the test duration was significantly extended to account for the relatively high volume-to-absorber area ratio $\left(100 \mathrm{~L} / \mathrm{m}^{2}\right)$ of the prototype:

1. Adjust solar simulator for irradiance of $\mathrm{G} \approx 600 \mathrm{Wm}^{-2}$ by taking readings at locations across the entire absorber surface with a Kipp and Zonen CMP6 pyrometer.

2. Fill tank with cold mains water. Activate evaporator wetting mechanism and remove temporary shading from absorber.

3. Disconnect resistive load bank from PV terminals. Measure characteristic IV performance curve of PV module using Daystar DS1000 tracer. Reconnect resistive load bank.

4. Repeat Step 3 after 2, 4 \& 6 hours of illumination then immediately switch off the solar simulator and leave to cool overnight.

5. Repeat Steps 1 to 5 on subsequent days until no significant day-to-day change in daily minimum and maximum tank temperature occurs.

The procedure featured 6 hour collection periods $\left(\mathrm{t}_{\mathrm{col}}=21600 \mathrm{~s}\right)$ and 18 hour retention periods $\left(\mathrm{t}_{\mathrm{ret}}=64800 \mathrm{~s}\right)$ repeated over four consecutive 24 hour periods. Recorded temperature time history results were error-checked and spatially averaged to determine overall average values of $T_{0}, T_{1}, T_{2}, T_{3}, T_{4}, T_{S}$ and $T_{a}$. These results were then used to determine heat transfer rates, corresponding thermal conductances and subsequently to determine thermal efficiencies according to Equations $1,2 \& 3$. Photovoltaic performance results $\left(V_{\mathrm{oc}}, \mathrm{I}_{\mathrm{sc}}, \mathrm{V}_{\mathrm{mpp}}, \mathrm{I}_{\mathrm{mpp}}\right.$,

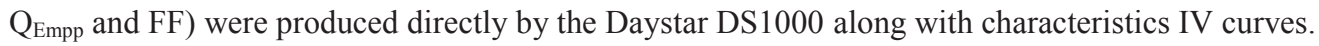

Table 1 - Specifications of the prototype

\begin{tabular}{|c|c|c|c|c|}
\hline & \multicolumn{2}{|c|}{ Value } & \multirow{2}{*}{$\begin{array}{l}\text { Basis / Reason } \\
\text { High strength, low vacuum outgassing, relatively low } \\
\text { thermal conductivity and emittance. }\end{array}$} \\
\hline $\begin{array}{l}\text { Tank and diode envelope and } \\
\text { structure construction material }\end{array}$ & & Stain & s steel & \\
\hline Diode cavity depth & & $m m$ & 70 & $\begin{array}{l}\text { Optimum value for compromise between forward and } \\
\text { reverse mode performance. }\end{array}$ \\
\hline \multirow{2}{*}{$\begin{array}{l}\text { Absorber-evaporator \& } \\
\text { condenser-tank plates } \\
\text { height and width }\end{array}$} & z & $m m$ & 1400 & \multirow{2}{*}{$\begin{array}{l}\text { Slender cavity aspect ratio }(z / x=20) \text { and modest plate } \\
\text { aspect ratio }(y / z=0.5) \text { to minimise reverse mode } \\
\text { vapour convection and optimise high temperature } \\
\text { liquid-vapour-liquid conductance. }\end{array}$} \\
\hline & $y$ & $m m$ & 700 & \\
\hline Plate thickness & $x_{1}$ & $m m$ & 1.2 & $\begin{array}{l}\text { Chosen for compromise between structural integrity, } \\
\text { cost and weight, whilst minimising number of struts. }\end{array}$ \\
\hline Sidewall thickness & $z_{w}$ & $m m$ & 0.9 & $\begin{array}{l}\text { Chosen for compromise }\left(z_{w} \approx 0.1 x_{w}\right) \text { between } \\
\text { structural integrity and minimal sidewall thermal } \\
\text { conductance, rounded up to nearest available gauge. }\end{array}$ \\
\hline Centre-centre spacing of struts & $d_{s s}$ & $m m$ & 70 & Chosen to be similar to cavity depth and strut length \\
\hline Strut tube diameter & $d_{s}$ & $\mathrm{~mm}$ & 8 & Compromise between structural integrity and \\
\hline Strut tube wall thickness & $d_{\text {sw }}$ & $m m$ & 0.9 & minimising structure thermal conductance. \\
\hline Mass of diode and tank & $\mathrm{m}_{1234 \mathrm{~s}}$ & $k g$ & 8.1 & \multirow{4}{*}{$\begin{array}{l}\text { Construction material and liquid masses determined } \\
\text { from dimensions given above together with densities } \\
\text { for stainless steel and liquid water ( } 7900 \text { and } \\
1000 \mathrm{~kg} \cdot \mathrm{m}^{-3} \text { respectively). }\end{array}$} \\
\hline Mass of diode working fluid & $\mathrm{m}_{\mathrm{Lv}}$ & $\mathrm{kg}$ & 1. & \\
\hline Mass of water stored in tank & $\mathrm{m}_{3 \mathrm{~L}}$ & $\mathrm{~kg}$ & 100 & \\
\hline Total mass & & $k g$ & 131 & \\
\hline Photovoltaic cells & & \multicolumn{2}{|c|}{$\begin{array}{l}\text { Monocrystalline } \\
\text { silicon }\end{array}$} & Bosch M-2BB high efficiency pseudo-square cells. \\
\hline Number of cells & $\mathrm{N}$ & \multicolumn{2}{|c|}{$8 \times 15=120$} & Formed of 30 whole cells cut into quarters. \\
\hline Cell size & $A_{0}$ & $m^{2}$ & $78 \times 78$ & Quarter of a standard 6x6 inch whole cell. \\
\hline Wiring scheme \& voltage & $\mathrm{V}_{\text {oc }}$ & $V$ & 23 & $\begin{array}{l}\text { Series-parallel configuration of } 8 \text { cells per string with } \\
3 \text { strings connected in parallel to form each bus } \\
\left(\mathrm{V}_{\text {oc }} \approx 4.5 \mathrm{~V}\right) \text {. Module consists } 5 \text { buses in series. }\end{array}$ \\
\hline Cell packing factor & PF & $\%$ & $72 \%$ & $\begin{array}{l}\text { Thermo-electrical efficiency compromise. Absorber } \\
\text { surface behind PV cells was painted matt black. }\end{array}$ \\
\hline Encapsulation & & \multicolumn{2}{|c|}{$\begin{array}{l}\text { Silicone resin } \\
\text { PlatSil@ 71-20 }\end{array}$} & $\begin{array}{l}\text { Low cost, highly transparent, pourable resin, resists } \\
\text { UV degradation and high temperatures. }\end{array}$ \\
\hline \multicolumn{2}{|c|}{$\begin{array}{l}\text { Bonded cover (on top of encapsulation) } \\
\text { Thermal cover (for air gap) }\end{array}$} & \multicolumn{2}{|c|}{$\begin{array}{l}\text { Clear } \\
\text { Perspex }\end{array}$} & Low cost, robust, resistant to UV degradation. \\
\hline \multirow{3}{*}{$\begin{array}{l}\text { Thickness of encapsulation and } \\
\text { bonded cover }\left(x_{15}=x_{01}+x_{05}\right)\end{array}$} & $\mathrm{x}_{15}$ & $m m$ & 5 & \multirow{5}{*}{$\begin{array}{l}\text { Perspex sheet minimum } 2 \mathrm{~mm} \text { available thickness. } \\
\text { Resin thickness determined by pour viscosity and } \\
\text { adhesive foam tape spacer thickness. }\end{array}$} \\
\hline & $\mathrm{x}_{01}$ & $m m$ & 1.5 & \\
\hline & $\mathrm{x}_{05}$ & $m m$ & 3.5 & \\
\hline Thickness of thermal cover & $\mathrm{x}_{6}$ & $m m$ & 2 & \\
\hline Thickness of air gap & $x_{56}$ & $\mathrm{~mm}$ & 35 & \\
\hline
\end{tabular}


1) Absorber-evaporator plate (e)

2) Condenser-tank mantle plate (c)

3) Water storage tank open at top but covered with insulation

4) Sidewalls (w) in the $x y$ and $x z$ planes. Supporting structure (s) consists of a tubular strut array

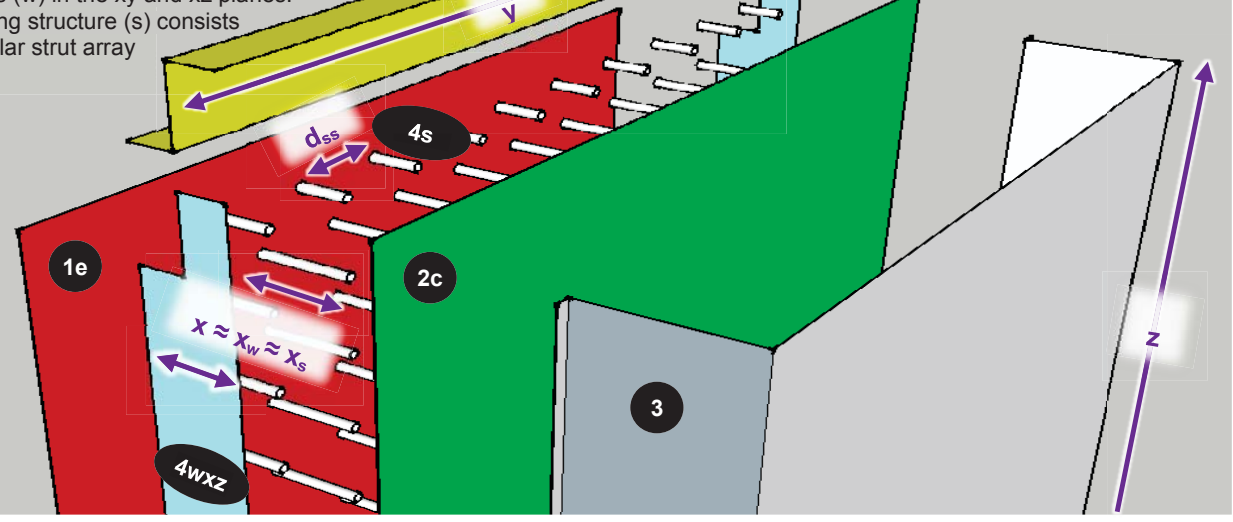

Figure 3 - Construction of the thermal diode and tank

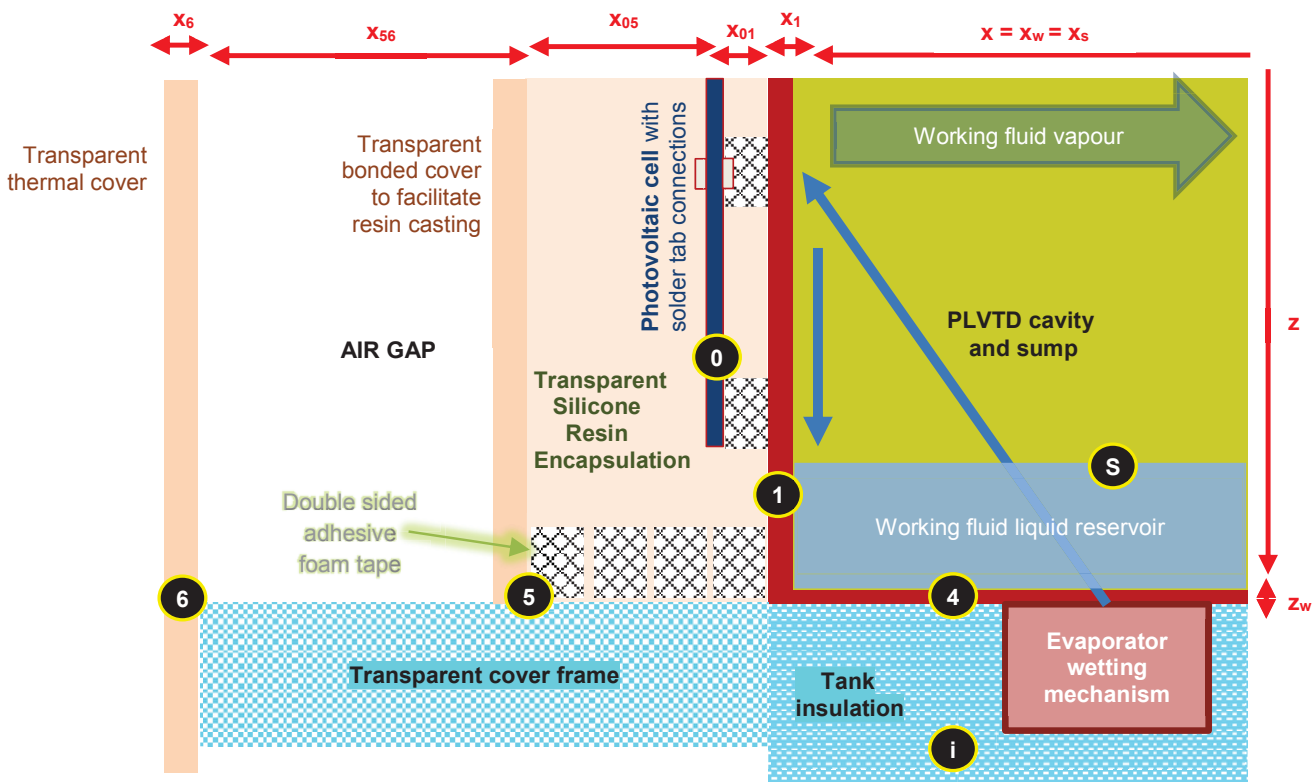

Figure 4 - Cross section through absorber laminate and transparent covers (scale exaggerated)
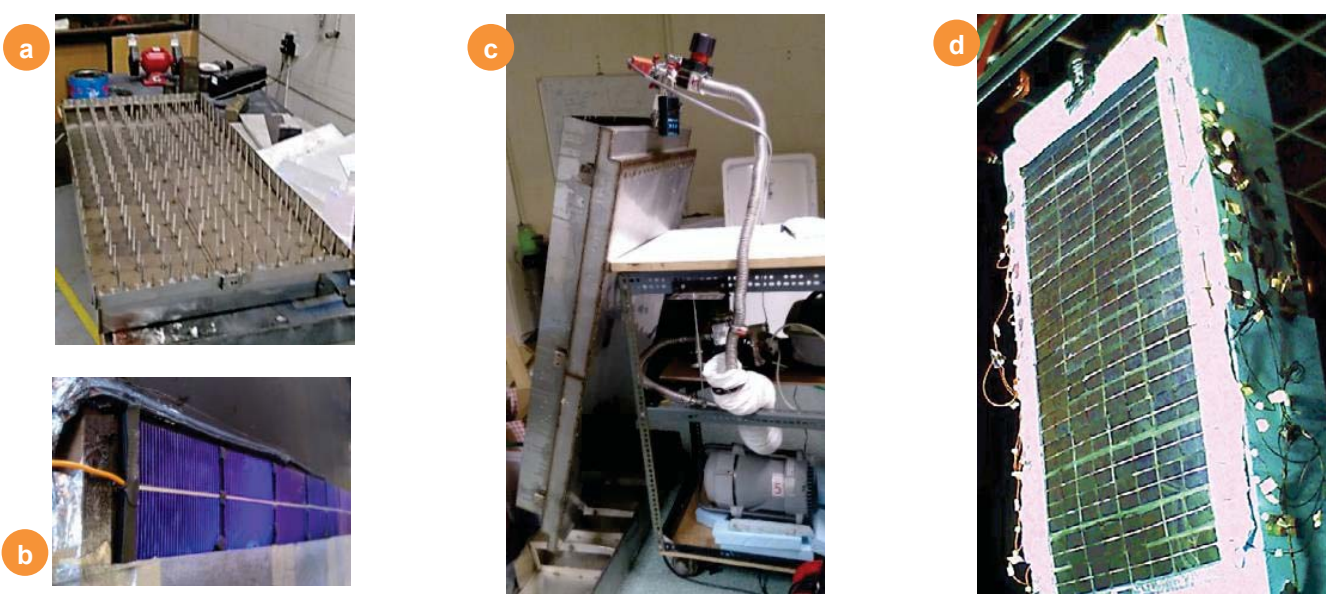

Figure 5 - Photographs showing steelwork \& PVT absorber fabrication (a \& b), leak testing (c), solar simulator testing (d) 


\section{Results and discussion}

Recorded temperature time histories are shown on Figure 6 . Tests began with $\mathrm{T}_{3}=17^{\circ} \mathrm{C}$ tank temperature which rose by $21^{\circ} \mathrm{C}$ during the first collection period and fell by only $5^{\circ} \mathrm{C}$ during the first overnight retention period. The final (fourth) day of collection saw only $11^{\circ} \mathrm{C}$ gain before reaching $\mathrm{T}_{3}=57^{\circ} \mathrm{C}$. This gain was almost entirely lost during the fourth overnight retention period. Ambient temperatures were $\mathrm{T}_{\mathrm{a}} \approx 25 \pm 5^{\circ} \mathrm{C}$ during collection and $\mathrm{T}_{\mathrm{a}} \approx 20 \pm 3{ }^{\circ} \mathrm{C}$ during retention periods. Instantaneous thermal and electrical efficiencies were $60 \%$ and $9 \%$ respectively at zero increased temperature $\left(\mathrm{T}_{3}-\mathrm{T}_{\mathrm{a}}=0\right)$, dropping to $40 \%$ and $6 \%$ respectively at a nominal intended operating condition $\sim 0.05 \mathrm{~m}^{2} \mathrm{KW}^{-1}$ corresponding to $\mathrm{T}_{3} \approx 50{ }^{\circ} \mathrm{C}, \mathrm{T}_{\mathrm{a}} \approx 20^{\circ} \mathrm{C}$ and $\mathrm{G} \approx 600 \mathrm{Wm}^{-2}$.

Dependence of the instantaneous thermal and electrical efficiencies upon the water storage tank temperature are shown on Figure 7 to be reasonably linear. Scatter in the data is primarily a manifestation of absorber heatup and cool-down transients which occurred at the beginning and end of each collection period due to the diode's significant thermal mass (sensible and latent). These transients were observed to affect PV module efficiency as well as absorber heat loss and diode thermal conductance. Electrical efficiencies recorded at the start of each day of testing, immediately after illumination whilst the absorber was cool $\left(\mathrm{T}_{1} \leqq \mathrm{~T}_{\mathrm{a}}+15^{\circ} \mathrm{C}\right)$, were consistently higher than values recorded at other times when the absorber was warmer (typically $\mathrm{T}_{1} \approx \mathrm{T}_{3}+8^{\circ} \mathrm{C}$ ). Recorded collection efficiencies each day were $\eta_{\text {col }}=65,46,44$ and $40 \%$. Overnight retention efficiency was $\eta_{\text {ret }}=71 \%$ with corresponding overall loss coefficient $\mathrm{U}_{\mathrm{sys}}=0.85 \mathrm{Wm}^{-2} \mathrm{~K}^{-1}$ (estimated standard uncertainty $\pm 0.1 \mathrm{Wm}^{-2} \mathrm{~K}^{-1}$ ). With reference back to Figure 2, diurnal thermal efficiencies recorded for Days 1 and 4 were slightly lower than predicted because of poorer than expected forward mode diode thermal conductances, but as predicted, were significantly higher than for the benchmark ICSSWH without thermal diode.

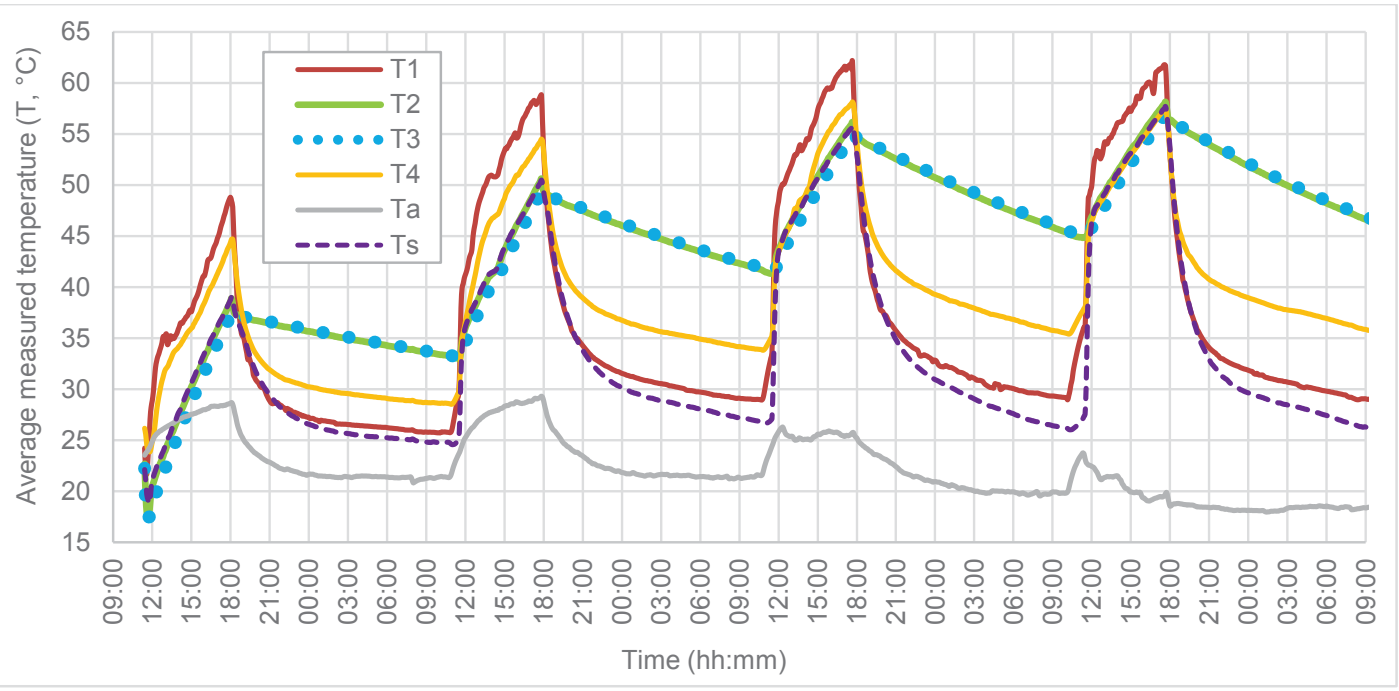

Figure 6 - Recorded temperature time history

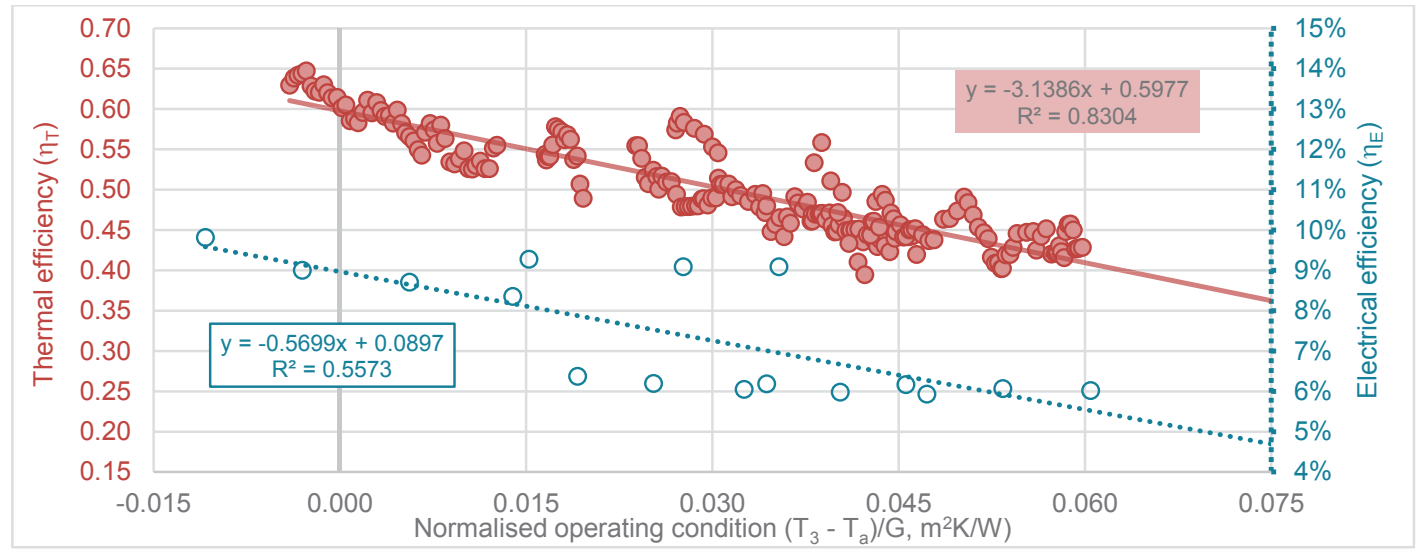

Figure 7 - Instantaneous thermal and electrical efficiencies 
Table 2 - Comparison of measured photovoltaic characteristics against manufacturers data

\begin{tabular}{|c|c|c|c|}
\hline Characteristic & $\begin{array}{l}\text { Manufacturer's } \\
\text { data for } \\
\text { single cell }\end{array}$ & $\begin{array}{l}\text { Expected } \\
\text { module } \\
\text { performance }\end{array}$ & $\begin{array}{l}\text { Actual module } \\
\text { performance } \\
\text { (with encapsulation } \\
\text { and bonded cover }{ }^{*} \text { ) }\end{array}$ \\
\hline Maximum Power at STC $\left(Q_{E m p p}, W\right)$ & 4.24 & 127 & $83^{*}$ \\
\hline Cell efficiency at STC $\left(\eta_{E(0, m p p)}, \%\right)$ & $17.6 \%$ & $17.6 \%$ & $11.4 \% *$ \\
\hline Module efficiency at STC ( $\left.\eta_{E(e c, m p p)}, \%\right)$ & - & $13.7 \%$ & $8.9 \% *$ \\
\hline Open Circuit Voltage at STC $\left(\mathrm{V}_{\mathrm{oc}}, \mathrm{V}\right)$ & 0.616 & 24.6 & $24.1^{*}$ \\
\hline Short Circuit Current at STC $\left(I_{s c}, A\right)$ & 8.9 & 6.7 & $4.8^{*}$ \\
\hline Fill Factor (FF, \%) & \multicolumn{2}{|c|}{$78 \%\left(\mathrm{G}=1000 \mathrm{Wm}^{-2}\right)$} & $74 \%(G=610)$ \\
\hline Voltage temperature coefficient $\left(\% \mathrm{~V}_{\mathrm{oc}} / \mathrm{K}\right)$ & \multicolumn{2}{|c|}{$-0.37 \%$} & $-0.37 \%$ \\
\hline Current temperature coefficient $\left(\% \mathrm{I}_{\mathrm{sc}} / \mathrm{K}\right)$ & \multicolumn{2}{|c|}{$+0.03 \%$} & $-0.19 \%$ \\
\hline Maximum power temperature coefficient (\% $\left.\mathrm{Q}_{\mathrm{Empp}} / \mathrm{K}\right)$ & \multicolumn{2}{|c|}{$-0.49 \%$} & $-0.55 \%$ \\
\hline \multicolumn{4}{|c|}{$\begin{array}{l}\left.\text { * Photovoltaic performance was measured under a variety of irradiances ( } \mathrm{G}=350,610 \text { and } 870 \mathrm{Wm}^{-2}\right) \text { and a variety of } \\
\text { temperatures, with the transparent thermally insulating cover removed. No measurements were made under strict } \\
\text { Standard Test Conditions (STC) of } G=1000 \mathrm{Wm}^{-2} \text { and } T_{0}=25^{\circ} \mathrm{C} \text { but the data obtained enabled STC open circuit voltage, } \\
\text { short circuit current, maximum power, and efficiency values to be determined by extrapolation. }\end{array}$} \\
\hline
\end{tabular}

Forward mode diode thermal conductances were typically an order of magnitude lower (worse) than expected, but the predicted temperature dependence was clearly apparent with $\mathrm{U}_{12 \mathrm{f}}=30 \mathrm{Wm}^{-2} \mathrm{~K}^{-1}$ occurring when the water storage tank was cold, rising to $\mathrm{U}_{12 \mathrm{f}}=70 \mathrm{Wm}^{-2} \mathrm{~K}^{-1}$ when it was hot. Considerable spatial variation in absorber surface temperature was observed during collection periods. Detailed investigations (Pugsley, 2017) found that the relatively poor forward mode diode performances were primarily caused by poor evaporator wetting. Wetted parts of the absorber-evaporator plate were typically observed to be $\mathrm{T}_{1} \approx \mathrm{T}_{3}+3^{\circ} \mathrm{C}$ (as expected) whereas "dry spots" were markedly hotter (typically $\mathrm{T}_{1} \approx \mathrm{T}_{3}+30^{\circ} \mathrm{C}$ ) due to the lack of evaporative cooling.

Reverse mode diode thermal conductances were generally slightly lower (better) than predicted being typically $\mathrm{U}_{12 \mathrm{r}}=1.7 \mathrm{Wm}^{-2} \mathrm{~K}^{-1}$. Other measured forward and reverse mode conductances were broadly as expected, being typically $\mathrm{U}_{23 \mathrm{f}}=250 \mathrm{Wm}^{-2} \mathrm{~K}^{-1}$ and $\mathrm{U}_{23 \mathrm{r}}=100 \mathrm{Wm}^{-2} \mathrm{~K}^{-1}$ within the water storage tank; $\mathrm{U}_{1 \mathrm{ff}}=3.5 \mathrm{Wm}^{-2} \mathrm{~K}^{-1}$ and $\mathrm{U}_{1 \mathrm{ar}}=2.5 \mathrm{Wm}^{-2} \mathrm{~K}^{-1}$ between the absorber and ambient; and $\mathrm{U}_{01} \approx 100 \mathrm{Wm}^{-2} \mathrm{~K}^{-1}$ through the silicone resin encapsulation bonding the PV cells to the absorber. Water storage tank thermal conductances $\left(\mathrm{U}_{23}\right)$ and absorber heat loss thermal conductances $\left(\mathrm{U}_{1 \mathrm{a}}\right)$ were higher during forward mode than during reverse mode because heat fluxes and plate temperatures were inherently higher during solar collection periods than they were during retention periods. The estimated combined standard uncertainty of the aforementioned thermal conductance results is about $\pm 30 \%$.

Measured PVT absorber electrical performance is summarised in Table 2. Short circuit current $\left(\mathrm{I}_{\mathrm{sc}}\right)$, maximum electrical power yield ( $\left.Q_{E m p p}\right)$, and efficiency $\left(\eta_{E}\right)$ were all 30-35\% lower than expected, despite results of pilot tests on individual cells being broadly consistent with manufacturer's data. Measured temperature coefficients for whole-module power $\left(\% \mathrm{Q}_{\mathrm{Empp}} / \mathrm{K}\right)$ and short circuit current $\left(\% \mathrm{I}_{\mathrm{sc}} / \mathrm{K}\right)$ were also notably worse than manufacturers single-cell values. Analysis described in detail by Pugsley (2017) identifies several potential causes for the poor current yield, of which the most significant is accidental cell damage (to approximately a quarter of all cells) which occurred during absorber laminate fabrication. Cell fractures function as electrical resistances which limit (or completely eliminate) the flow of current between broken cell fragments and the main body of each cell. Detailed inspection of the test data indicated an abrupt worsening of current loss above $\mathrm{T}_{1} \approx 45^{\circ} \mathrm{C}$ which is thought to be due to absorber thermal expansion widening fractures and increasing associated electrical resistances. In addition to cell fractures, the following effects are also likely to have contributed to current and power loss:

- Uneven distribution of light emitted by the solar simulator ( $\pm 10 \%$ for high irradiance tests) causing some cells to produce less current than others, thereby limiting overall string currents.

- Optical losses associated with delamination of the encapsulation material, which was particularly notable in locations where the aforementioned hot "dry spots" occurred. 
- Non-uniform absorber surface temperatures which caused voltage mismatches between parallel connected cell strings. The hot "dry-spots" on the absorber-evaporator plate were observed to be most pronounced when the absorber and/or the tank were cool and irradiance levels were high.

Despite the lower than expected diode forward mode thermal conductance and underperforming PV cell array, the solar thermal collection and retention performances of the prototype are amongst the highest reported anywhere in the ICSSWH literature (see Sections 1.1 \& 1.2) providing strong evidence that incorporation of a planar liquid-vapour thermal diode yields a significant performance benefit. This finding is echoed in the comparative study reported by Smyth et al. (2016).

\section{Supporting analyses}

In addition to the work presented above, a considerable amount of additional experimental and theoretical work and supporting analyses have been undertaken as part of this study (Pugsley, 2017) and will be the subject of several anticipated future papers:

- Theoretical behavior of PLVTDs: A lumped parameter thermal resistance model enabling prediction of PLVTD heat transfer was developed and experimentally validated. The model was used to undertake a parametric study examining PLVTD behaviour under different heat flux, temperature, and tilt angle conditions. The model was also used to optimize the PLVTD design in respect of material choices; working fluid types and flow rates; dimensions and aspect ratios.

- Economics: Materials for the prototype cost $£ 600 / \mathrm{m}^{2}$. This cost is comparable to typical retail prices of flat plate and evacuated tube solar thermal collectors and is considerably less than most commercially available packaged solar water heaters. Estimated labour costs were very high $\left(£ 2000 / \mathrm{m}^{2}\right)$ due to reliance on labour intensive processes required to fabricate a one-off prototype. Significant value engineering and manufacturing process optimization would be required to make the device commercially viable and mass-manufacturable.

- Building integration: Feasibility studies were undertaken to examine how the PVT-PLVTDICSSWH concept might be integrated into different building façade constructions, allowing for key considerations such as structural loading and aesthetic/dimensional compatibility with building structural grids. The compatibility of the device in respect of integration into building electrical and heating services systems was also examined.

\section{Conclusions}

A flat panel Integrated Collector-Storage Solar Water Heater (ICSSWH) incorporating a photovoltaic-thermal (PVT) absorber and a Planar Liquid-Vapour Thermal Diode (PLVTD) was fabricated and tested under Ulster University's solar simulator. The collector primarily consisted of a sealed evacuated thermal diode and a vented water storage tank, both constructed of welded and folded stainless steel sheet. The absorber-evaporator plate was painted black and 120 quartered monocrystalline photovoltaic cells were encapsulated and bonded to it using clear silicone resin. Cells were interconnected in a series-parallel configuration to produce an open circuit voltage of $\sim 24 \mathrm{~V}$. The absorber was insulated by a transparent Perspex cover and air gap. Collector rear and sides were insulated by polystyrene foam.

Test results indicate instantaneous thermal and electrical efficiencies of $60 \%$ and $9 \%$ respectively under zero temperature rise conditions (when stored water temperature equals ambient temperature), dropping to $40 \%$ and $6 \%$ at the nominal intended operating condition $\left(\sim 0.05 \mathrm{~m}^{2} \mathrm{KW}^{-1}\right.$ at $20^{\circ} \mathrm{C}$ ambient). Water temperature of $57^{\circ} \mathrm{C}$ was achieved in the 100 Litre tank after four days of consecutive 6-hour collection periods $\left(\mathrm{G}=610 \mathrm{Wm}^{-2}\right.$ irradiance on $\sim 0.95 \mathrm{~m}^{2}$ absorber) and 18 hour retention periods $\left(\mathrm{T}_{\mathrm{a}} \approx 20 \pm 3^{\circ} \mathrm{C}\right)$. Daily solar thermal collection and overnight heat retention efficiencies of $\eta_{\mathrm{col}}=65 \%$ and $\eta_{\mathrm{ret}}=71 \%$ were achieved, corresponding to diurnal thermal efficiency of up to $\eta_{T+E, 24}=46 \%$ and an overall heat loss coefficient of $\mathrm{U}_{\mathrm{sy}}=0.85 \mathrm{Wm}^{-2} \mathrm{~K}^{-1}$. Measured thermal diode conductances were typically $\mathrm{U}_{12 \mathrm{f}}=45 \mathrm{Wm}^{-2} \mathrm{~K}^{-1}$ in forward mode (during collection periods) and $\mathrm{U}_{12 \mathrm{r}}=1.7 \mathrm{Wm}^{-2} \mathrm{~K}^{-1}$ in reverse mode (during retention periods). These thermal performances are comparable to 
the best ICSSWH collector designs encountered in the literature. Photovoltaic performance was lower than expected, primarily owing to accidental damage to PV cells during fabrication, together with temperature and irradiance non-uniformities, and optical losses associated with delaminated encapsulation.

Overall, the work demonstrates that ICSSWH, PVT and PLVTD concepts can be successfully combined to create a scalable flat panel solar collector suitable for integration within a multifunction building facade. Changes to fabrication procedures could reduce or eliminate breakage of PV cells. Improved evaporator wetting, reduced PV cell encapsulation thickness, and better bonding of PV cells to the absorber plate would all increase conductance during collection periods yielding improvements to both thermal and electrical efficiencies. It is recommended that further work focusses on implementing the aforementioned improvements and undertaking further studies to optimize the design for building façade and services systems integration.

\section{Nomenclature}
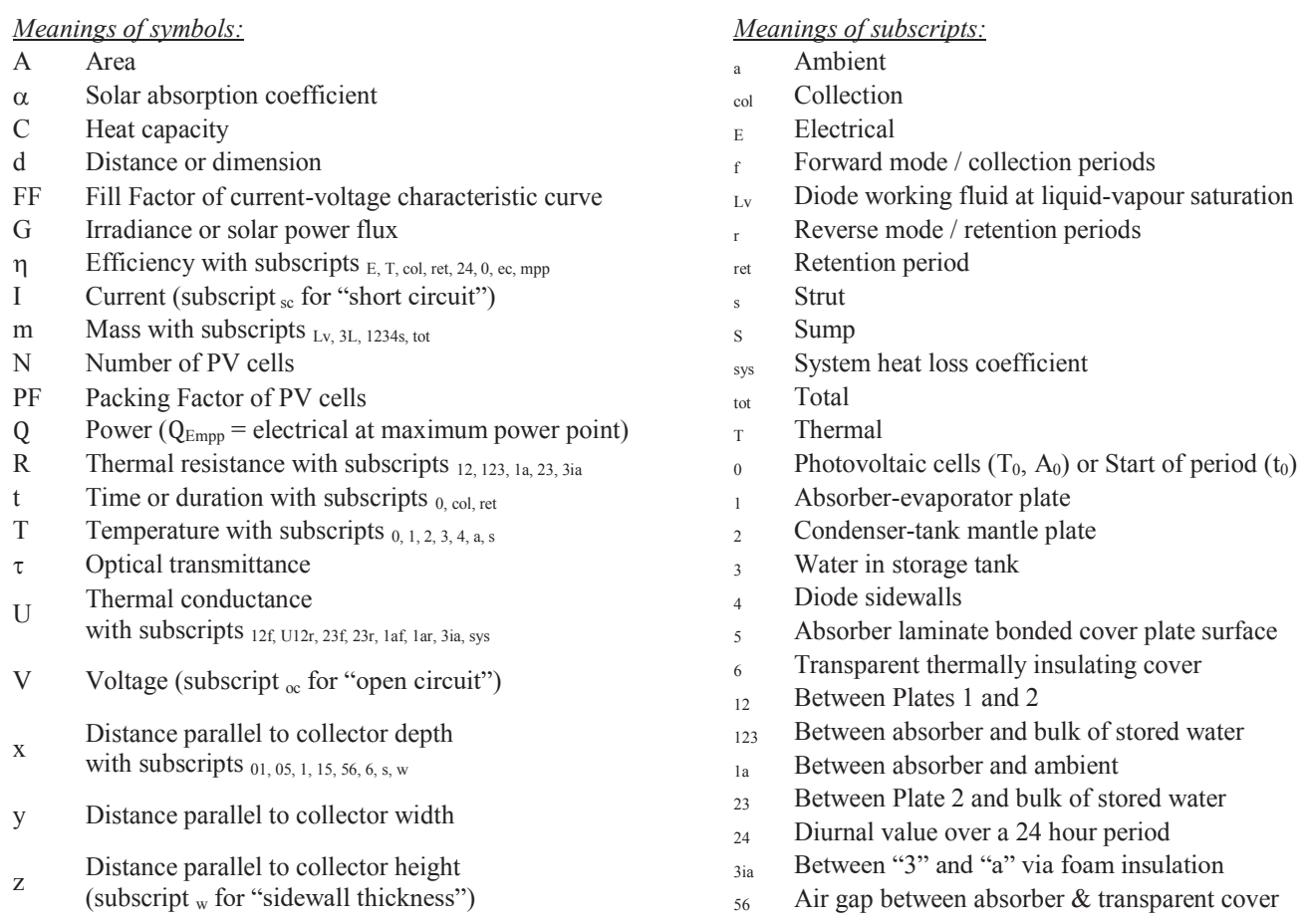

\section{References}

Aguilar, F., Aledo, S. Quiles, P., 2016. Experimental study of the solar photovoltaic contribution for the domestic hot water production with heat pumps in dwellings. App. Therm. Eng. 101, 379-89

Besheer, A., Smyth, M., Zacharopoulos, A., Mondol, J., Pugsley, A. 2016. Review on recent approaches for hybrid PV/T solar technology. Int. J. Energy Res. DOI: 10.1002/er.3567

Boreyko, J., Zhao, Y., Chen, C., 2011. Planar jumping-drop thermal diodes. Appl. Phys. Lett. 99, 234105

Boreyko, J. and Chen, C., 2013. Vapor chambers with jumping-drop liquid return from superhydrophobic condensers. Int. J. Heat \& Mass Trans. 61, 409-18

Calise, F., d'Accadia, M, Figaj, R., Vanoli, L., 2016. A novel solar-assisted heat pump driven by photovoltaic/thermal collectors: Dynamic simulation and thermoeconomic optimization. Energy 95, 346-66

Cengel, Y., Boles, M., 2006. Thermodynamics an Engineering Approach, 5th Edition. McGraw-Hill, New York.

Chen, K., Chailapo, P., Chun, W., Kim, S., Lee, K., 1998. Dynamic behavior of a bayonet-type thermal diode. Sol. Energy $64,257-63$

De Beijer, H., 1998. Product development in solar water heating. Ren. Energy 5, 201-4

Dupeyrat, P., Menezo, C., Rommel, M., Henning, H., 2011. Efficient single glazed flat plate photovoltaic-thermal hybrid collector for domestic hot water systems. Sol. Energy 85, 1457-68

Faiman, D., Hazan, H., Laufer, I., 2001. Reducing the Heat Loss at Night from Solar Water Heaters of the Integrated Collector-Storage Variety, Sol. Energy, 71, 87-93 
Fang, Y., Hyde, T., Arya, F., Hewitt, N., Eames, P., Norton, B., Miller, S., 2014. Indium alloy-sealed vacuum glazing development and context. Renewable and Sustainable Energy Reviews 37 (2014) 480-501.

Fang, X., Xia, L., 2010. Heating performance investigation of a bidirectional partition fluid thermal diode. Ren. Energy 35, 679-84

Good, C., Andresen, I., Hestnes, A., 2015. Solar energy for net zero energy buildings - A comparison between solar thermal, PV and photovoltaic-thermal (PV/T) systems. Sol. Energy 122, 986-96

Kolodziej, A., Jaroszynski, M., 1997, Performance of liquid convective diodes. Sol. Energy 61, 321-6

Michael, J., Iniyan, S., Goic, R., 2015. Flat plate solar photovoltaic-thermal (PV/T) systems. Ren. \& Sus. Energy Rev. 51, 62-88

Mohamad, A., 1997. Integrated Solar Collector-Storage Tank System with Thermal Diode. Sol. Energy, 61, 211-8.

Pugsley, A., 2017. Theoretical and experimental analysis of a novel flat photovoltaic-thermal solar water heater with integrated energy storage via a Planar Liquid-Vapour Thermal Diode. Ulster University PhD Thesis. Available at: <http://ethos.bl.uk/SearchResults.do $>$

Poppi, S., Bales, C., Haller, M., Heinz, A., 2016. Influence of boundary conditions and component size on electricity demand in solar thermal and heat pump combisystems. App. Energy 162, 1062-73

Qu, M., Chen, J., Nie, L., Li, F., Yu, Q., Wang, T., 2016. Experimental study on the operating characteristics of a novel photovoltaic/thermal integrated dual-source heat pump water heating system. App. Therm. Eng. 94, 819-26.

Quinlan, P., 2010. The Development of a Novel Integrated Collector Storage Solar Water Heater (ICSSWH) Using Phase Change Materials and Partial Evacuation. PhD Thesis, University of Ulster.

Quinlan, P., Smyth, M., Griffiths, P., Conway, S. and Filippi, A., 2008. Novel Integrated Collector Storage Solar Water Heater Utilising Phase Change Materials. Proceedings World Renewable Energy Conference, 19-25 July 2008, Glasgow, UK.

European Union (EU) Directive 2009/28/EC on the promotion of the use of energy from renewable sources and amending and subsequently repealing Directives 2001/77/EC and 2003/30/EC (Text with EEA relevance). Official Journal of the European Union.

Rhee, J., Campbell, A., Mariadass, A., Morhous, B., 2010. Temperature stratification from thermal diodes in solar hot water storage tank Sol. Energy 84, 507-511.

Santbergen, R., Rindt, C., Zondag, H., Van Zolingen, R., 2010. Detailed analysis of the energy yield of systems with covered sheet-andtube PVT collectors. Sol. Energy 84, 867-78.

Singh, R., Lazarus, I., Souliotis, M., 2016. Recent developments in integrated collector storage (ICS) solar water heaters: A review. Ren. \& Sus. Energy Rev. 54, 270-98.

Smyth, M., 2015. A solar water heater. Patent WO2010052010.

Smyth, M., Eames, P., Norton, B., 1999. A comparative performance rating for an integrated solar collector/storage vessel with inner sleeves to increase heat retention. Sol. Energy 66, 291-303.

Smyth, M., Eames, P., Norton, B., 2006. Integrated Collector Storage Solar Water Heaters. Ren. \& Sus. Energy Rev. 10(6), 503-38.

Smyth, M., Besheer, A., Zacharopoulos, A., Mondol, J., Pugsley, A., Novaes, M., 2015. Experimental evaluation of a Hybrid Photovoltaic/Solar Thermal (HyPV/T) Façade Module. Proceedings EURO ELECS Conference 21-23 July 2015, Guimarães, Portugal.

Smyth, M., Pugsley, A., Hanna, G., Zacharopoulos, A., Mondol, J., Besheer, A., 2016. Experimental performance comparison of a Hybrid Photovoltaic/Solar Thermal (HyPV/T) Façade Module with a flat ICSSWH module. Proceedings BIRES 2017 Conference 6-10 March 2016, Dublin, Ireland.

Solaform, nd. SolaCatcher Innovative, cost effective solar water heating system. http://solaform.com/ [accessed 2016-19-09].

Sopian, K.,Syahri, M., Abdullah, S., Othman, M.,Yatim, B., 2004. Performance of a non-metallic unglazed solar water heater with integrated storage system. Ren. Energy 29, 1421-30.

Souliotis, M., Quinlan, P., Smyth, M., Tripanagnostopoulos, Y., Zacharopoulos, A., Ramirez, M., Yianoulis, P., 2011. Heat retaining integrated collector storage solar water heater with asymmetric CPC reflector. Sol. Energy 85, 2474-87.

Zacharopoulos, A., Mondol, J., Smyth, M., Hyde, T., O'Brien, V., 2009. State of the Art Solar Simulator with Flexible Mounting. Proceedings ISES Solar World Congress, 11-14 October 2009, Johannesburg, South Africa, pp 854-863.

Zondag, H., 2008. Flat-plate PV-thermal collectors and systems: a review. Ren. \& Sus. Energy Rev. 12, 891-959. 